\title{
Literature Study: Highway Traffic Management with Sentiment Analysis and Data Mining
}

\author{
Nurul Khairina ${ }^{1 *}$, Muhammad Khoiruddin Harahap ${ }^{2}$ \\ ${ }^{1}$ Universitas Medan Area, Indonesia, ${ }^{2}$ Politeknik Ganesha Medan, Indonesia \\ ${ }^{1}$ nurulkhairina27@gmail.com, ${ }^{2}$ choir.harahap@yahoo.com
}

open

access

\section{*Corresponding Author}

Article History:

Submitted: $\mathrm{xx}$

Accepted: $\mathrm{xx}$

Published: $x x$

Keywords:

HIghway; Traffic; Management;

Sentiment Analysis; Data Mining

Brilliance: Research of

Artificial Intelligence is licensed

under a Creative Commons

Attribution-NonCommercial 4.0

International (CC BY-NC 4.0).

\begin{abstract}
In today's era, technology is growing rapidly, many of the latest technologies are in great demand by the Indonesian people, one of which is social media. Various social media such as Facebook, Twitter, Instagram, have become very popular applications for various ages, including teenagers, adults, and the elderly. Social media has a positive impact that can help people convey the latest information through posts on their respective accounts. Social media can disseminate information in a short time, this is why social media is an interesting application to research. The problem of road traffic congestion is strongly influenced by the number of vehicles that pass every day. A large number of private vehicles and public vehicles that pass greatly confuses the atmosphere of highway traffic. Congestion often occurs during working hours. Road congestion also often occurs when an unwanted incident occurs. Sentiment analysis algorithms and data mining algorithms can be combined to find information on traffic jams through social media such as Facebook, Twitter, Instagram, and other social media. The results show that sentiment analysis methods and data mining algorithms can be used to find information about current traffic jams through social media. The conclusion from this literature study can be seen that the K-Nearest Neighbor data mining algorithm is the best choice to overcome road traffic congestion, which will then be further developed in the form of highway traffic management modeling.
\end{abstract}

\section{INTRODUCTION}

Medan city is one of the largest provincial capitals in Indonesia. Medan City is a metropolitan city that has a fairly large population and reaches 2 million inhabitants per the year 2015 [1]. The number of private vehicles and public transportation often triggers traffic jams on the highway during working hours. According to Kartika Ratnasari, Medan is the 6th most congested city in Indonesia. The length of traffic jams in Medan in a year reaches 42 hours with a percentage of $20 \%$. The percentage of time drivers are stuck in traffic jams reaches $25 \%$ during working hours and $23 \%$ outside working hours [2].

Natural disasters such as earthquakes, landslides, strong winds, tsunamis, and so on can also disrupt the flow of highway traffic. In addition, events such as demonstrations, student brawls, going home on National holidays, road repairs, Covid-19 prevention checks, zebra operations, traffic light damage, traffic accidents, and so on can also cause long traffic jams and take up time for drivers. According to Rozie Winata, the number of traffic accidents in 2019 has increased in 2018. Throughout 2019 there were 6,100 cases, while previously in 2018 there were only 5,990 cases. In addition, Kapolda also said that material losses due to traffic accidents in 2019 decreased, which was only Rp. 12,625,000,000, while in 2018 it previously reached Rp. 13,696,830,000 [3].

Minister of Transportation Budi Karya Sumadi said that traffic jams in urban areas had a major impact on the Indonesian economy. One of them inhibits economic growth[4]. In 2016, SITRAMP (Study on Integrated Transportation Master Plan) also estimated that losses due to congestion could reach Rp 12.8 trillion per year[5]. Until now, the Medan City Government continues to strive to overcome road traffic congestion, one of which is by building toll roads and flyovers[6]. In this study, the researcher plans to conduct a literature review of the sentiment analysis algorithm and data mining algorithm to find alternative solutions for handling traffic jams in terms of the field of informatics engineering which will also involve social media [7][8]. Several theories will be analyzed and tested to help the government overcome road traffic congestion.

\section{LITERATURE REVIEW}

As for previous research related to this research, Arvian Zanuardi \& Hitapriya Suprayitno researched by applying Knowledge Discovery to the database to analyze the characteristics of traffic accidents in Surabaya [9]. Zuhri Muhis and Wahju Herijanto conducted a study that focused on traffic management due to trams on the Surabaya highway with the 
theory of Traffic Demand Management [10]. Laif Satoinong et al conducted a study that focused on performance analysis and traffic management at the ITS Roundabout and the Mulyosari Roundabout in Surabaya using the MKJI theory [11]. Popy Purnamasari Wahid Suyitno et al conducted a study by detecting traffic congestion in Jakarta with the Data Mining C4.5 algorithm and offering solutions to overcome traffic congestion [12]. Putu Amelia Vennanda Widyaswari et al conducted a study on the classification of traffic congestion in the city of Malang using the Neighbor Weighted K-Nearest Neighbor method [13]. Siti Nurwahyuni researched the form of sentiment analysis on the KRL Access Online Transportation Application using the Naïve Bayes method [14]. Myrna Ermawati and Joko Lianto Buliali conducted a study using a text-based approach to find out similar traffic incidents through social media Twitter[15].

\section{METHOD}

This literature review study was conducted to determine whether sentiment analysis and data mining algorithms can prevent road traffic congestion through road traffic management. The literature review was conducted on three studies [13] [15] [16] by analyzing the algorithms and cases to be solved as can be seen in Table 1. below:

Tabel 1. Review Paper

\begin{tabular}{|c|c|c|c|}
\hline Author & Title & Algorithm & Case \\
\hline $\begin{array}{l}\text { Putu Amelia } \\
\text { Vennanda } \\
\text { Widyaswari, } \\
\text { Indriati, } \\
\text { Rizal Setya } \\
\text { Perdana }\end{array}$ & $\begin{array}{l}\text { Malang City } \\
\text { Traffic } \\
\text { Congestion } \\
\text { Classification } \\
\text { Through } \\
\text { Twitter Media } \\
\text { Using the } \\
\text { Neighbor } \\
\text { Weighted K- } \\
\text { Nearest } \\
\text { Neighbor (NW- } \\
\text { KNN) Method }\end{array}$ & $\begin{array}{l}\text { Neighbor } \\
\text { Weighted K- } \\
\text { Nearest } \\
\text { Neighbor } \\
(\text { NW-KNN) }\end{array}$ & $\begin{array}{l}\text { Traffic } \\
\text { congestion }\end{array}$ \\
\hline $\begin{array}{l}\text { Myrna } \\
\text { Ermawati, } \\
\text { Joko Lianto } \\
\text { Buliali }\end{array}$ & $\begin{array}{l}\text { Text Based } \\
\text { Approach For } \\
\text { Similar Traffic } \\
\text { Incident } \\
\text { Detection from } \\
\text { Twitter }\end{array}$ & $\begin{array}{l}\text { Text Based } \\
\text { Approach }\end{array}$ & $\begin{array}{l}\text { Trafic } \\
\text { Incident }\end{array}$ \\
\hline $\begin{array}{l}\text { Amani } \\
\text { AlFarasani, } \\
\text { Tahani } \\
\text { AlHarthi, } \\
\text { Sarah } \\
\text { AlHumoud }\end{array}$ & $\begin{array}{l}\text { ATAM: Arabic } \\
\text { Traffic } \\
\text { Analysis Model } \\
\text { for Twitter }\end{array}$ & $\begin{array}{l}\text { Sentiment } \\
\text { Analysis, } \\
\text { support vector } \\
\text { machines }\end{array}$ & $\begin{array}{l}\text { Road } \\
\text { Incident } \\
\text { Prediction }\end{array}$ \\
\hline
\end{tabular}

\section{RESULT}

The results of the literature review carried out by researchers can be in the form of comparative analysis of research results, research gaps, and the advantages and disadvantages of the three studies [13][15][16] that have been described in Table 1. The results of the literature review can be seen in Table 2 below:

Table 2

Comparative Analysis of Three Research on Sentiment Analysis and Data Mining

\begin{tabular}{|c|c|c|}
\hline Algorithm & $\begin{array}{l}\text { Object of } \\
\text { Research }\end{array}$ & Research Result \\
\hline $\begin{array}{l}\text { Neighbor } \\
\text { Weighted K- } \\
\text { Nearest } \\
\text { Neighbor } \\
\text { (NW-KNN) }\end{array}$ & $\begin{array}{l}\text { Traffic } \\
\text { congestion }\end{array}$ & $\begin{array}{l}\text { The average value of } \\
\text { precision is } 0.7336507 \text {, } \\
\text { recall is } 0.2210526 \text {, and } \\
\text { accuracy is } 0.665\end{array}$ \\
\hline Text Based & Trafic & Best average f-measure \\
\hline
\end{tabular}




\begin{tabular}{|c|c|c|}
\hline Approach & Incident & $\begin{array}{l}70 \% \text { was achieved by } \\
\text { retrieval system that tested } \\
\text { using jaccard coefficient }\end{array}$ \\
\hline $\begin{array}{l}\text { Sentiment } \\
\text { Analysis, } \\
\text { Support } \\
\text { Vector } \\
\text { Machines }\end{array}$ & $\begin{array}{l}\text { Road Incident } \\
\text { Prediction }\end{array}$ & $\begin{array}{l}\text { The overall accuracy was } \\
82 \% \text { for all four classes }\end{array}$ \\
\hline
\end{tabular}

Table 3

Research Gap from Three Research on Sentiment Analysis and Data Mining

\begin{tabular}{|c|c|c|}
\hline Algorithm & $\begin{array}{l}\text { Object of } \\
\text { Research }\end{array}$ & Research Gap \\
\hline $\begin{array}{l}\text { Neighbor } \\
\text { Weighted K- } \\
\text { Nearest } \\
\text { Neighbor } \\
\text { (NW-KNN) }\end{array}$ & $\begin{array}{l}\text { Traffic } \\
\text { congestion }\end{array}$ & $\begin{array}{l}\text { Optimizing the performance of } \\
\text { the Neighbor Weighted K- } \\
\text { Nearest Neighbor (NW-KNN) } \\
\text { algorithm to overcome traffic } \\
\text { jams }\end{array}$ \\
\hline $\begin{array}{l}\text { Text Based } \\
\text { Approach }\end{array}$ & Trafic Incident & $\begin{array}{l}\text { Optimizing traffic incident } \\
\text { detection with semantic } \\
\text { analysis }\end{array}$ \\
\hline $\begin{array}{l}\text { Sentiment } \\
\text { Analysis, } \\
\text { Support } \\
\text { Vector } \\
\text { Machines }\end{array}$ & $\begin{array}{l}\text { Road Incident } \\
\text { Prediction }\end{array}$ & $\begin{array}{l}\text { Build a web service for live } \\
\text { streaming and classifications. }\end{array}$ \\
\hline
\end{tabular}

After determining the results from the three articles [13][15][16], their strengths and weaknesses were reviewed, as shown in Table 4.

Table 4

Strengths and Weaknesses from Three Research on Sentiment Analysis and Data Mining

\begin{tabular}{|c|c|c|}
\hline Title & Strength & Weakness \\
\hline $\begin{array}{l}\text { Malang City } \\
\text { Traffic } \\
\text { Congestion } \\
\text { Classification } \\
\text { Through Twitter } \\
\text { Media } \\
\text { Using the } \\
\text { Neighbor } \\
\text { Weighted K- } \\
\text { Nearest } \\
\text { Neighbor (NW- } \\
\text { KNN) Method }\end{array}$ & $\begin{array}{l}\text { Able to detect } \\
\text { congestion by } \\
\text { providing } \\
\text { information in the } \\
\text { form of time, place, } \\
\text { road congestion } \\
\text { conditions, and } \\
\text { weather conditions }\end{array}$ & $\begin{array}{l}\text { In some trials there } \\
\text { is still low accuracy, } \\
\text { this is due to a large } \\
\text { number of test data } \\
\text { with } \\
\text { incorrect conditions, } \\
\text { such as test data that } \\
\text { should be in the } \\
\text { crash category are } \\
\text { included in the non- } \\
\text { jammed category. }\end{array}$ \\
\hline $\begin{array}{l}\text { Text Based } \\
\text { Approach For } \\
\text { Similar Traffic } \\
\text { Incident } \\
\text { Detection from } \\
\text { Twitter }\end{array}$ & $\begin{array}{l}\text { Able to filter } \\
\text { sentences without } \\
\text { symbols/punctuation } \\
\text { from Twitter, can } \\
\text { extract hashtags, } \\
\text { conditions, } \\
\text { locations, and } \\
\text { objects }\end{array}$ & $\begin{array}{l}\text { Unable to } \\
\text { distinguish the } \\
\text { presence of different } \\
\text { words with the same } \\
\text { meaning in a traffic } \\
\text { incident, for } \\
\text { example, the terms } \\
\text { 'consecutive } \\
\text { collision' and } \\
\text { 'accident' } \\
\text { streak'. }\end{array}$ \\
\hline
\end{tabular}




\begin{tabular}{lll} 
ATAM: Arabic & $\begin{array}{l}\text { Able to detect traffic } \\
\text { Traffic Analysis } \\
\text { incidents in the form } \\
\text { of safe conditions, } \\
\text { noed attention, } \\
\text { Twitter }\end{array}$ & $\begin{array}{l}\text { Still need Arabic } \\
\text { speakers to measure } \\
\text { the accuracy of word } \\
\text { classification }\end{array}$ \\
& & \\
\hline
\end{tabular}

\section{DISCUSSION}

After conducting a literature study on sentiment analysis and data mining algorithms in the three studies listed in Table 2, Table 3, and Table 4, the researcher has a further research plan to build a highway traffic management model, as detailed in Figure 1 below:

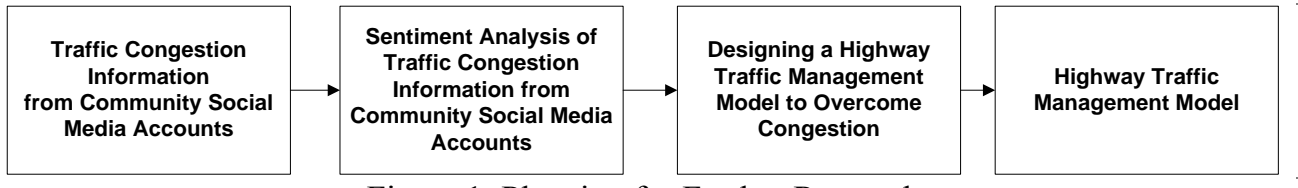

Figure 1. Planning for Further Research

\section{CONCLUSION}

The literature study is an initial study to explore how sentiment analysis and data mining algorithms work, especially in traffic management, which will be useful for overcoming traffic congestion. After the researchers analyzed the three studies in Table 2, Table 3, and Table 4, it can be seen that the sentiment analysis method and data mining algorithm can be used to detect traffic congestion through social media. From the literature study, it can also be seen that the right data mining algorithm to use is K-Nearest Neighbor. For further research, researchers will build a traffic management model to avoid congestion, this is based on the results of literature studies on sentiment analysis methods and data mining algorithms.

\section{REFERENCES}

1. P. Medan, "Kependudukan," 13 November 2013. [Online]. Available: https://pemkomedan.go.id/halkependudukan.html.

2. K. Ratnasari, "Daftar Kota Termacet di Indonesia," 13 August 2020. [Online]. Available: https://artikel.rumah123.com/daftar-kota-termacet-di-indonesia-ternyata-bukan-jakarta-yang-terparah-54016.

3. R. Winata, "Kasus Laka Lantas di Kota Medan," 6 January 2020. [Online]. Available: https://medanbisnisdaily.com/news/online/read/2020/01/06/97415/kasus_dan_korban_laka_lantas_di_sumut_men ingkat/.

4. Y. A. Uly, "Kemacetan Menghambat Pertumbuhan," 5 August 2020. [Online]. Available: https://money.kompas.com/read/2020/08/05/150600726/menhub--kemacetan-di-perkotaan-hambat-pertumbuhanekonomi-.

5. D. Subinarto, "Medan, Maet, dan Resiko Ekonomi," 13 October 2016. [Online]. Available: http://www.umm.ac.id/en/opini/medan-macet-dan-resiko-ekonomi.html.

6. W. A. Siregar, "Groundbreaking Tol Dalam Kota Medan Dimulai Februari 2020," 15 January 2020. [Online]. Available: https://economy.okezone.com/read/2020/01/15/320/2153232/groundbreaking-tol-dalam-kota-medandimulai-februari-2020? page $=1$.

7. Y. Tao, F. Zhang, C. Shi and Y. Chen, "Social Media Data-Based Sentiment Analysis of Tourists' Air Quality Perceptions," Sustainability, vol. 11, no. 5070, pp. 1-23, 2019.

8. A. Giachanou and F. Crestani, "Like It or Not: A Survey of Twitter Sentiment Analysis Methods," ACM Computing Surveys, vol. 49, no. 2, pp. 28-41, 2016. 
9. A. Zanuardi and H. Suprayitno, "Analisa Karakteristik Kecelakaan Lalu Lintas di Jalan Ahmad Yani Surabaya melalui Pendekatan Knowledge Discovery in Database," Jurnal Manajemen Aset Infrastruktur \& Fasilitas, vol. 2, no. 1, pp. 45-55, 2018.

10. Z. Muhis and W. Herijanto, "Manajemen Lalu Lintas Akibat Trem Di Jalan Raya Darmo Surabaya," Jurnal Teknik Pomits, vol. 3, no. 1, pp. 37-42, 2014.

11. L. Satoinong, Mardijono, M. Donny, N. Ray and L. S. B. Wibowo, "Analisis Kinerja Dan Manajemen Lalu Lintas pada Bundaran ITS dan Bundaran Mulyosari Kota Surabaya," Jurnal Perencanaan dan Rekayasa Sipil, vol. 2, no. 1, pp. 16-22, 2019.

12. P. P. W. Suyitno, R. E. Indrajit and M. Fauzi, "Penerapan Data Mining dalam Menangani Kemacetan di Jakarta," Ikraith-Informatika, vol. 1, no. 2, pp. 53-60, 2017.

13. P. A. V. Widyaswari, Indriati and R. S. Perdana, "Klasifikasi Kemacetan Lalu Lintas Kota Malang Melalui Media Twitter Menggunakan Metode Neighbor Weighted K-Nearest Neighbor (NW-KNN)," Jurnal Pengembangan Teknologi Informasi dan Ilmu Komputer, vol. 3, no. 2, pp. 1464-1470, 2019.

14. S. Nurwahyuni, "Analisis Sentiment Aplikasi Transportasi Online KRL Access Menggunakan Metode Naive Bayes," Jurnal Swabumi, vol. 7, no. 1, pp. 31-38, 2019.

15. M. Ermawati and J. L. Buliali, "Text Based Approach For Similar Traffic Incident Detection from Twitter," Lontar Komputer, vol. 9, no. 2, pp. 63-71, 2018.

16. A. AlFarasani, T. AlHarthi and S. AlHumoud, "ATAM: Arabic Traffic Analysis Model for Twitter," International Journal of Advanced Computer Science and Applications (IJACSA), vol. 10, no. 3, pp. 328-336, 2019. 